DOI: https://doi.org/10.24127/ajpm.v9i4.3175

\title{
POSITIVE AND NEGATIVE UNDERSTANDING MONITORING CALON GURU DALAM PENYUSUNAN SOAL CERITA PECAHAN
}

\author{
Dedi Kusnadi ${ }^{*}$, Irianto Aras ${ }^{2}$, A.Wilda Indra Nanna ${ }^{3}$, Enditiyas Pratiwi ${ }^{4}$ \\ $1^{*}, 2,3,4$ Universitas Borneo Tarakan, Kalimantan Utara, Indonesia \\ *Corresponding author. \\ E-mail: $\quad$ dedikusnadi4289@gmail.com ${ }^{1 *}$ \\ arasirianto1990@gmail.com $^{2)}$ \\ wiradjab@gmail.com ${ }^{3)}$ \\ enditiyaspratiwi.endit@gmail.com $^{4)}$
}

Received 20 October 2020; Received in revised form 07 December 2020; Accepted 18 December 2020

\begin{abstract}
Abstrak
Tujuan penelitian ini untuk mendeskripsikan self-explanation mahasiswa terhadap penyusunan soal cerita materi pecahan. Penelitian ini merupakan penelitian kualitatif yang menggunakan teknik pengumpulan data dengan memberikan tes yang ditindaklanjuti dengan wawancara untuk menggali lebih dalam tentang pemahaman keputusan yang diambil. Hasil yang diperoleh dalam penelitian ini, yaitu: (1) pada soal pertama, partisipan memunculkan perbedaan pada kategori positive dan negative understanding monitoring; (2) pada soal kedua, perbedaan yang muncul pada kategori elaboration of problem. Temuan dalam penelitian ini, yaitu jika partisipan melibatkan pemahaman maka keputusan yang diambil memunculkan positive understanding monitoring dan sebaliknya jika tidak melibatkan pemahaman maka keputusan yang diambil memunculkan negative understanding monitoring. Namun, terdapat partisipan yang hanya mengandalkan pengalaman dalam membuat soal dan berakhir dengan positive understanding monitoring.
\end{abstract}

Kata kunci: menyusun; pecahan; penjelasan diri; soal cerita

\begin{abstract}
The purpose of this study to describe the self-explanation of the pre-service teachers on how they draft the fraction material story words. This research is qualitative. The data collected in this study employs tests and interviews. The reason why conducting interviews is to acquire data deeply in understanding the decisions taken. Based on the result of analyzing the data, it shows that: (1) in the first question, participants showed differences in the positive and negative understanding in monitoring categories; (2) in the second question, the differences that appear in the elaboration of problem category. The finding in this study shows if the participants involve understanding, the decisions taken will give rise to positive understanding monitoring. Moreover, if it does not involve understanding, the decisions taken will give rise to negative understanding monitoring. However, some participants only rely on their experiences in making questions and finish it with positive understanding monitoring.
\end{abstract}

Keywords: creating; fraction; self-explanation; students; word problem

This is an open access article under the Creative Commons Attribution 4.0 International License

\section{PENDAHULUAN}

Pendidikan yang berkualitas bisa dihasilkan dari guru berkulaitas dan profesional. Kompetensi guru profesional berarti memiliki kualifikasi yang kompleks, keterampilan dan disposisi yang menjadi prasayarat untuk keberhasilan kinerja profesi (Tichá \& Hošpesová, 2013). Guru profesional bisa dilihat berdasarkan kompetensi yang dimilikinya, salah satunya adalah kompetensi pedagogik. Kompetensi guru dalam menerapkan proses belajar mengajar terkait dengan pengetahuan 
mengajar (pedagogik) dan konten (pengetahuan materi) yang dikenal sebagai pedagogical content knowledge (PCK) (Safriani et al., 2019). Gagasan awal (Shulman, 2019) tentang pengetahuan konten dan pengetahuan pedagogik mendefenisikan PCK sebagai pengetahuan tentang gambaran, penjelasan dan contoh yang digunakan dalam membuat materi pelajaran lebih komprehensif bagi siswa. Bagian dari komponen dalam PCK yang harus dimiliki oleh guru profesional adalah kemampuan menyusun soal cerita.

Cara guru dalam menyajikan permasalahan dalam bentuk cerita (baik tertulis maupun tidak) telah terbukti berpengaruh langsung terhadap kemampuan siswa dalam memahami masalah berbentuk soal cerita (Hadi \& Kadir, 2017). Oleh karena itu, kemampuan menyusun soal cerita juga dibutuhkan oleh mahasiswa calon guru dalam mengembangkan masalah ke dalam bentuk cerita yang terhubung dengan situasi kehidupan sehari-hari.

Beberapa penelitian pada mahasiswa calon guru yang membahas kemampuan menyusun soal cerita pecahan menunjukkan kelemahan calon guru dalam pemahaman konsep pengurangan pecahan, kesulitan melakukan representasi ataupun penjelasan terhadap bentuk pecahan dan mengabaikan aspek konseptual pecahan sehingga memunculkan berbagai macam kesalahan (Dixon et al., 2014; Hadi \& Kadir, 2017; Işik \& Kar, 2012). Bilangan pecahan memang sulit dipelajari dan diajarkan (Nanna \& Pratiwi, 2020; Newton, 2008; Pratiwi et al., 2019a), terutama bagaimana mentransfer (kontekstualisasi dan dekontekstualisasi) soal-soal pecahan biasa menjadi soal cerita.

Pada dasarnya kesulitan menyusun soal pada materi pecahan ini bisa diatasi melalui strategi kognitif, feed-back, maupun manipulatif virtual dengan bantuan komputer (Shin \& Bryant, 2017), namun tetap saja pemantauan secara akurat bagi tiap mahasiswa sulit dilakukan (Baars et al., 2018). Hal ini dapat dibenarkan karena adanya kesulitan dalam mendampingi mahasiswa satu persatu untuk memastikan kesulitan apa yang mereka temui dalam menyusun soal cerita materi pecahan. Mahasiswa yang mengalami kesulitan cenderung menunjukkan self-explanation yang tidak dapat dikomunikasikan secara eksplisit dalam menyelesaikan masalah yang diberikan (Nokes-Malach et al., 2013).

Self-explanation memiliki komponen kunci dalam prosesnya, yaitu mengidentifikasi sesuatu yang tidak dapat dipahami seseorang dan kemudian mencoba menjelaskannya dengan membuat kesimpulan dan merevisi pengetahuan atau kesalahpahaman sebelumnya (Chi, 2000). Selfexplanation diarahkan pada diri sendiri untuk tujuan membuat informasi baru yang bermakna secara pribadi (Bisra et al., 2018). Karena self-explanation diarahkan pada diri sendiri, maka dalam prosesnya dapat terselubung dan dapat pula diungkapkan secara terbuka serta hanya dapat dipahami oleh siswa itu sendiri. Self-explanation dipengaruhi oleh perbedaan pemahaman individu dan tingkat kerumitan kalimat dalam teks, sehingga dapat mendorong peserta didik dalam memanipulasi, menghubungkan, dan mengevaluasi informasi untuk meningkatkan hasil pembelajaran di berbagai domain (DeCaro \& Rittle-Johnson, 2012).

Self-explanation dapat mendorong peserta didik menjelaskan pengetahuan konseptual dan prosedural yang benar atau salah melalui tiga aktivitas, yaitu 
membandingkan, menjelaskan sendiri, dan mengeksplorasi (Rittle-johnson, 2004; Rittle-Johnson, 2017; RittleJohnson et al., 2017). Self-explanation merupakan mekanisme pembelajaran penting yang mendasari akuisisi pemecahan masalah yang fleksibel dengan atau tanpa petunjuk secara langsung (Rittle-johnson, 2004), di mana dapat memediasi proses belajar peserta didik untuk menjadi pemecah masalah yang baik (Fuchs et al., 2015). Hal tersebut menunjukkan bahwa, selfexplanation dapat menjadi strategi metakognitif.

Selain sebagai strategi metakognitif, self-explanation dapat diperiksa secara menyeluruh melalui kategori berikut ini (Renkl, 1997): (1) Anticipative reasoning: penjelasan menggunakan penalaran untuk memprediksi tindakan selanjutnya; (2) Principle-based explanation: penjelasan yang mengacu pada prinsip domain yang terkait dengan tindakan, operasi, dan solusi; (3) Goal-action combinations: penjelasan tentang asosiasi antara tujuan dan tindakan; (4) Elaboration of problem situations: penjelasan tentang konteks masalah dan pada kondisi seperti apa tindakan solusi dilakukan; (5) Noticing coherence; penjelasan tentang koherensi hubungan antara teks, contoh dan masalah; (6) Negative understanding monitoring: penjelasan tentang pemahaman yang salah; dan (7) Positive understanding monitoring: penjelasan tentang materi yang dipahami.

Beberapa penelitian terkait selfexplanation, menggunakannya sebagai strategi dalam proses pembelajaran untuk disampaikan ketika menyelesaikan masalah (Bisra et al., 2018; Fuchs et al., 2016). Strategi self-explanation yang digunakan dalam menyelesaikan masalah dapat diterapkan dalam berbagai situasi. Hal tersebut disebabkan self-explanation dapat memberikan pemetaan terhadap kognitif siswa sehingga dapat secara optimal mengetahui pemahaman yang dimilikinya. Selain itu, (Durkin, 2011) juga menggunakan self-explanation untuk melihat efeknya dalam pemecahan masalah matematika, khususnya pada soal cerita (Tajika et al., 2007). Namun, belum ditemukan penelitian yang menggunakan self-explanation ketika proses penyusunan soal cerita matematika. Oleh karena itu, perlu dilakukan penelitian untuk mendeskripsikan self-explanation mahasiswa calon guru SD terhadap masalah matematika, khususnya dalam penyusunan soal cerita matematika.

\section{METODE PENELITIAN}

Metode yang digunakan dalam penelitian ini adalah deskriptif kualitatif yang bertujuan mendeskripsikan selfexplanation mahasiswa terhadap penyusunan soal cerita materi pecahan. Instrumen utama dalam penelitian ini adalah peneliti sendiri dan akan dibantu instrumen pendukung yaitu lembar tes dan pedoman wawancara. Penelitian ini dilaksanakan dalam empat tahap.

Tahap pertama dilaksanakan melalui pemberian instrumen lembar tes yang berupa operasi perkalian pecahan, kemudian calon partisipan diminta untuk menyusun soal cerita berdasarkan model matematika yang terdapat pada lembar tes. Calon partisipan dalam penelitian ini adalah 36 mahasiswa PGSD. Lembar tes diberikan melalui whatsapp group mata kuliah Pengembangan Matematika SD. Calon partisipan diminta untuk menyelesaikan lembar tes dalam waktu 30 menit dan hanya 21 mahasiswa yang mengembalikan lembar hasil tes. Kemudian, 21 mahasiswa tersebut 
DOI: https://doi.org/10.24127/ajpm.v9i4.3175

dijadikan sebagai partisipan dalam penelitian ini.

Pada tahapan kedua, hasil lembar tes dari partisipan dikelompokkan dengan menggunakan kriteria pada komponen pengunaan kata dalam wacana matematis (Mpofu \& Pournara, 2018). Kriteria yang dimaksud adalah colloquial dan literate yang dapat dilihat pada Tabel 1 .

Tabel 1. Penggunaan kata dalam wacana matematis

\begin{tabular}{lll}
\hline Komponen Wacana Matematis & Klasifikasi & \multicolumn{2}{c}{ Deskripsi } \\
\hline Penggunaan Kata & Colloquial & $\begin{array}{l}\text { Kombinasi pengunaan kata } \\
\text { matematis dan kata yang } \\
\end{array}$ \\
& digunakan sehari-hari \\
& Literate & Pengunaan kata matematis \\
\hline
\end{tabular}

Dari hasil pengelompokan pada tahapan kedua ini diperoleh informasi terdapat 13 partisipan pada klasifikasi colloquial dan 8 partisipan pada klasifikasi literate. Selanjutnya pada tahapan ketiga, dilakukan wawancara terhadap dua orang partisipan yang mewakili masing-masing klasifikasi dan dipilih berdasarkan kesalahan dalam penggunaan kata ketika menyusun soal cerita. Partisipan klasifikasi colloquial selanjutnya disebut partisipan A dan partisipan klasifikasi literate disebut partisipan B.

Tahapan keempat dalam penelitian ini yaitu menganalisis hasil wawancara partisipan A dan B untuk mendeskripsikan self-explanation ketika menyusun soal cerita pecahan. Data lembar hasil tes partisipan A dan B dianalisis kemudian dilanjutkan dengan proses wawancara terhadap kedua partisipan. Wawancara dilakukan dengan tujuan mengetahui kategori selfexplanation yang muncul. Pelaksanaan wawancara merupakan bagian dari proses triangulasi data dengan membandingkan antara hasil analisis pada lembar tes dan recording hasil wawancara pada partisipan A dan B.

\section{HASIL DAN PEMBAHASAN}

Pada bagian ini akan dipaparkan mengenai self-explanation dua partisipan pada klasifikasi colloquial dan klasifikasi literate yaitu partisipan A dan partisipan B dalam menyusun soal cerita materi pecahan. Partisipan diarahkan untuk menyusun soal cerita dari model matematika yang diberikan, kemudian diminta untuk memberi penjelasan berdasarkan kategori Renkl (1997) yaitu principle-based explanation (penjelasan berdasarkan prinsip), anticipative reasoning (penalaran antisipatif), goal-action combinations (penjelasan tentang asosiasi antara tujuan dan tindakan), elaboration of problem situations (perincian tentang situasi masalah), noticing coherence (penjelasan tentang hubungan), negative understanding monitoring (pemantauan pemahaman negatif), dan positive understanding monitoring (pemantauan pemahan positif).

Tabel 2 memaparkan hasil lembar tes soal pertama pada partisipan A dan B. 
DOI: https://doi.org/10.24127/ajpm.v9i4.3175

Tabel 2. Hasil lembar tes soal pertama.

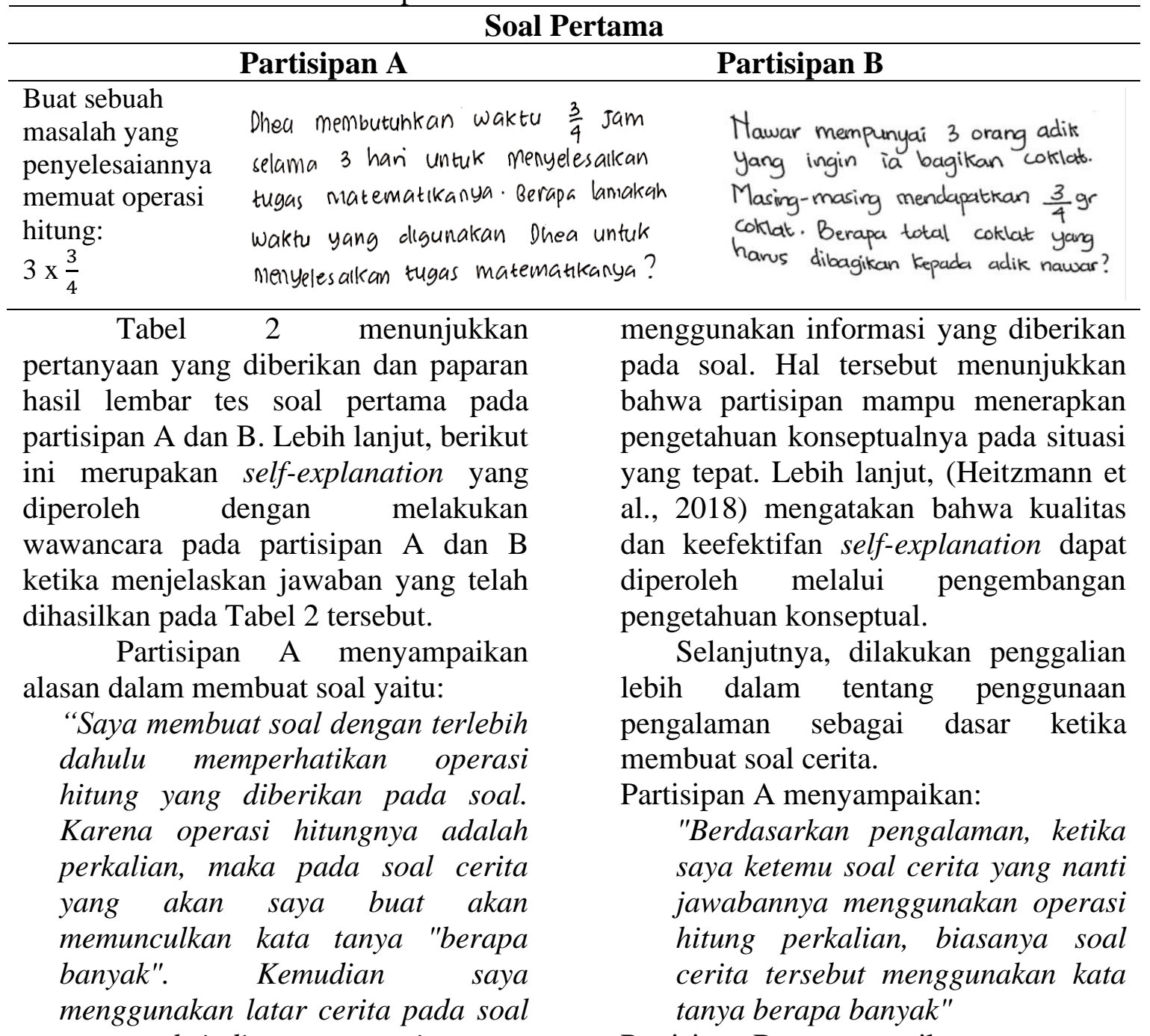
tentang kejadian yang sering saya alami saja, pada soal ini yaitu tentang waktu."

Sementara, partisipan B menyampaikan alasan dalam membuat soal yaitu:

"Saya membuat soal berdasarkan pengalaman ketika masih sekolah serta ketika mendampingi adik belajar Matematika dan saya sering menemukan tipe soal yang seperti itu"

Berdasarkan hasil wawancara, nampak jelas bahwa partisipan A dan B mampu menjelaskan secara mandiri apa yang dilakukannya untuk menyelesaikan soal dengan

Partisipan B menyampaikan:

"Ketika ingin memberikan sesuatu kepada banyak orang, berarti operasi hitung yang digunakan adalah perkalian. Sehingga pada soal cerita yang saya buat, saya menggunakan situasi cerita yang menunjukkan memberikan atau membagikan coklat kepada 3 orang adik."

Berdasarkan hasil konfirmasi jawaban melalui wawancara, ditemukan bahwa partisipan A dan B menggunakan informasi pada soal berupa operasi hitung perkalian kemudian dikaitkan dengan pengalaman sebelumnya. Berdasarkan Renkl (1997) partisipan A dan B melakukan 
anticipative reasoning, yaitu penjelasan menggunakan alasan pengalaman menemukan tipe soal untuk melanjutkan langkah kerjanya. Kondisi tersebut menunjukkan bahwa partisipan A dan B menggunakan informasi tidak langsung berdasarkan pengalaman dalam pembelajarannya. Sesuai dengan itu (Koedinger et al., 2012) menyatakan bahwa pengetahuan, pembelajaran dan instruksi yang digunakan dapat memunculkan memori, kelancaran, pemahaman dan langkah-langkah solusi yang tepat. Selain itu, Tajika et al. (2007) menunjukkan bahwa ketika siswa pertama kali menanggapi langkah-langkah solusi dari setiap contoh yang dikerjakan maka akan menyelesaikan dengan struktur serupa dengan contoh yang dikerjakan.

Selanjutnya, ingin diketahui apakah soal yang dibuat oleh partisipan sudah memuat operasi penyelesaian yang diinginkan. Partisipan A menyampaikan:

"Sudah membuat soal cerita sesuai dengan informasi yang diberikan pada soal, yaitu menunjukkan $3 x$ 3/4."

Partisipan B menyampaikan:

"Sudah, karena total coklat yang akan dibagikan kepada 3 orang adik merupakan hasil perkalian dari 3 dan 3/4."

Berdasarkan Renkl

partisipan A dan B melakukan goalaction combination, yaitu membuat soal cerita dengan secara langsung memperhatikan hasil akhir atau jawaban soal. (Baars et al., 2018) mengungkapkan bahwa siswa yang memiliki kemampuan dalam memperhatikan pengetahuan dapat membuat pilihan solusi yang tepat dalam proses pembelajaran yang sedang mereka jalani.
Lebih lanjut ingin diketahui penjelasan pada setiap partisipan terkait kondisi di atas, yaitu goal-action combination. Partisipan A dan B menyampaikan hal yang sama, yaitu:

"Karena di dalam soal yang saya buat sudah terdapat informasi angka 3 dan 3/4."

Berdasarkan Renkl (1997) partisipan A dan B melakukan principle-based explanation, yaitu penjelasan yang merujuk kepada langkah penyelesaian hitung dan solusinya. Hal ini sejalan dengan (Killingsworth et al., 2015) yang mengamati kualitas selfexplanation yang menjelaskan bahwa siswa dapat dengan mudah diarahkan ke jawaban yang tepat dalam setiap kondisi jika dalam bimbingan. Selain itu, siswa yang mampu melakukan refleksi dengan benar terhadap pemahaman mereka akan cenderung terlibat dalam principlebased explanation.

Namun, yang menarik adalah partisipan A dan B tidak mengaitkan antara soal cerita yang telah berhasil dibuat dengan teksnya kembali. Partisipan A menyampaikan:

"Tidak. Karena saya merasa sudah sesuai, jadi saya tidak membaca kembali soal cerita tersebut apa sudah sesuai dengan maksud pada operasi hitung perkalian pada soal."

Partisipan B menyampaikan:

"Tidak. Karena coklat yang dibagikan tersebut seharusnya hasil dari operasi hitung perkalian 3 dan 3/4."

Berdasarkan informasi pada hasil konfirmasi wawancara di atas, partisipan A dan B tidak melakukan pengecekan kembali sehingga tidak mengetahui apakah soal cerita yang dibuat sudah benar ataukah salah. Berdasarkan Renkl (1997) partisipan A dan B melakukan noticing coheren, 
yaitu penjelasan tentang hubungan antara teks, contoh dan masalah yang dibuat. Selain itu, partisipan A juga tidak mengaitkan antara soal cerita yang dibuat dengan bagaimana jawaban yang akan dihasilkan. Namun ketika dikonfirmasi melalui wawancara terkait soal cerita yang sudah dibuat, partisipan A mengalami pertentangan.

"Saya pikir sudah sesuai, namun kok rasanya berbeda ya antara apa yang saya maksud dengan yang sudah saya tuliskan ini. Nanti jawabannya juga bisa berbeda."

Konfirmasi tersebut menunjukkan adanya pertentangan antara apa yang dibaca (teks) dengan soal cerita yang dibuat (kontekstual) sehingga partisipan A mengakui adanya kesalahan dalam membuat soal cerita tersebut. Pratiwi et al., (2019) mengatakan bahwa pertentangan antara tekstual dan kontesktual dapat menyebabkan konflik. Hal tersebut menunjukkan bahwa partisipan A menemukan positive understanding monitoring, yaitu penjelasan yang berakhir dengan memahami bagaimana membuat soal cerita yang kontekstual. Sementara, partisipan B meyakini bahwa konteks soal cerita yang dibuat sudah sesuai dengan teks yang diberikan pada soal.

Hal tersebut menunjukkan bahwa partisipan $\mathrm{B}$ berakhir dengan negative understanding monitoring, yaitu penjelasan yang berakhir dengan kegagalan dalam memahami bagaimana membuat soal cerita yang kontekstual. (Heitzmann et al., 2018) mengemukakan bahwa self-explanation dapat merugikan jika siswa tidak dapat menggunakannya dengan baik. Kondisi tersebut memungkinkan partisipan B melakukan operasi hitung yang sudah sesuai namun pada kalimat soal cerita yang dibuat belum sesuai dengan konteksnya. Hal yang terjadi ketika penyusunan soal cerita pada soal pertama ini adalah partisipan A dan B menunjukkan perbedaan pada kategori positive dan negative understanding monitoring.

Tabel 3 memaparkan hasil lembar tes soal kedua pada partisipan A dan B.

Tabel 3. Hasil lembar tes soal kedua.

\begin{tabular}{|c|c|c|}
\hline \multicolumn{3}{|c|}{ Soal Kedua } \\
\hline & Partisipan A & Partisipan B \\
\hline $\begin{array}{l}\text { Buat sebuah } \\
\text { masalah yang } \\
\text { penyelesaiannya } \\
\text { memuat operasi } \\
\text { hitung: } \\
1 / 2 \times 2 / 3\end{array}$ & $\begin{array}{l}\text { Sebuah resep untuk kue bolu memerlukan } \\
\frac{2}{3} \text { gelas tepung. Ridho akan membuat } \\
\frac{1}{2} \text { dari resep tersebut. Berapa banyak } \\
\text { tepung yang Redho gunakan? }\end{array}$ & $\begin{array}{l}\text { Nawar memakan wakku sekitar } \\
\frac{1}{2} \text { jam untuk sampai dikampus. } \\
\frac{2}{3} \text { dari walktu perjalanan nawar } \\
\text { mengalami kemacetan. Berapa } \\
\text { lama uaktu yang dibutuhkan } \\
\text { untuk sampai di kampus jika } \\
\text { tidak terjadi kemacetan? }\end{array}$ \\
\hline
\end{tabular}

\section{Tabel 3 menunjukkan} pertanyaan yang diberikan dan paparan hasil lembar tes soal kedua pada partisipan A dan B. Lebih lanjut, berikut ini merupakan self-explanation yang diperoleh dengan melakukan wawancara pada partisipan A dan B ketika menjelaskan jawaban yang telah dihasilkan pada Tabel 3 tersebut.

Partisipan A menyampaikan alasan dalam membuat soal kedua sama seperti tipe soal pertama, yaitu:

"Karena soal kedua ini juga memuat operasi hitung perkalian maka saya 
juga menggunakan kata tanya "berapa banyak" ketika membuat soal cerita. Saya memilih latar cerita pada soal tentang membuat kue."

Sementara, partisipan B menyampaikan alasan dalam membuat soal yaitu:

"Saya ingin membuat soal cerita yang berbeda dengan soal pertama. Saya menginginkan tahapan berpikir yang harus dilakukan ketika seseorang mencoba untuk menyelesaikan soal cerita yang saya buat."

Berdasarkan hasil wawancara di atas, nampak jelas perbedaan alasan antara partisipan A dan B. Partisipan A menyelesaikan dengan pola yang sama antara soal pertama dan kedua. Sedangkan, partisipan B menyelesaikan dengan pola berbeda, yaitu mempertimbangkan tingkat kesulitan antara soal pertama dan kedua.

Kemudian dilakukan penggalian penggunaan pengalaman sebagai dasar dalam membuat soal cerita. Partisipan A menyampaikan:

"Karena resep kue tersebut dapat dibuat utuh dengan 2/3 tepung, akan tetapi juga bisa membuat setengah resep, sehingga memerlukan 1/2 dari 2/3 tepung. "

Partisipan B menyampaikan:

"Soal saya inginnya seperti ini, saya sampai di kampus setengah jam karena terjebak macet selama 2/3 dari setengah jam. Kemudian, yang saya tanyakan, jika tidak terjebak macet maka saya butuh waktu berapa lama untuk sampai di kampus?"

Berdasarkan hasil konfirmasi jawaban melalui wawancara di atas, ditemukan bahwa partisipan A dan B menggunakan informasi pada soal berupa operasi hitung perkalian kemudian dikaitkan dengan pengalaman selama ini di temukan dan juga ketika mengerjakan soal cerita yang berkaitan dengan operasi hitung. Berdasarkan Renkl (1997) partisipan A dan B melakukan anticipative reasoning, yaitu penjelasan menggunakan alasan pengalaman menemukan tipe soal untuk melanjutkan langkah kerjanya. Lebih lanjut, pada partisipan $B$ juga memunculkan goal-action combination, yaitu ketika membuat soal cerita langsung memperhatikan hasil akhir atau jawaban soal. Akan tetapi, pada partisipan A tidak memunculkan goalaction combination, yang muncul adalah principle-based explanation, yaitu hanya memperhatikan operasi hitung perkalian yang kemungkinan muncul pada soal cerita. Hal tersebut dikonfirmasi melalui penjelasan ini:

"Menurut saya, soal cerita yang dibuat sudah menunjukkan perkalian dari 1/2 dan 2/3."

Pada partisipan B, memunculkan elaboration of problem situation, yaitu penjelasan tentang masalah dan kondisi dimana memerlukan pendalaman pengetahuan terhadap solusi yang dibutuhkan. Hal tersebut dikonfirmasi melalui penjelasan ini:

"Ketika membuat soal cerita ini, saya memikirkan bagaimana menghasilkan soal cerita yang membutuhkan logika ketika menjawabnya. Sehingga saya menggabungkan antara pecahan dan waktu menjadi satu dalam soal cerita."

Konfirmasi tersebut menunjukkan menyempurnakan dan memperluas konteks masalah pada soal yang diajukan. Melalui penyempurnaan dan perluasan konteks masalah yang dilakukan dapat mengarahkan kognitif partisipan ke dalam bentuk skema pemecahan masalah yang mendasar. 
Sehingga kapasitas pemrosesan kognitif dapat diproses secara minimal dengan menggunakan self-explanation (Wang \& Adesope, 2017).

Namun, yang menarik adalah partisipan A dan B tidak mengaitkan antara soal cerita yang telah berhasil dibuat dengan teksnya kembali. Partisipan A dan B menyampaikan:

"Tidak. 1/2 $x$ 2/3 sudah muncul pada soal cerita yang saya buat."

Berdasarkan informasi pada hasil konfirmasi wawancara di atas, partisipan A dan B tidak melakukan pengecekan kembali sehingga tidak mengetahui apakah soal cerita yang dibuat sudah benar ataukah salah. Berdasarkan (Renkl, 1997) partisipan A dan B melakukan noticing coheren, yaitu penjelasan tentang hubungan antara teks, contoh dan masalah yang dibuat. (Hadi \& Kadir, 2017) menyatakan bahwa dengan mempelajari matematika berdasarkan situasi nyata maka siswa dapat mengkonstruksi pengetahuan secara mandiri sehingga dengan mudah memahami masalah dan tidak melakukan kesalahan penyelesaian.

Partisipan A dan B mengakui adanya kesalahan pada penyusunan kalimat dalam membuat soal cerita. Partisipan A menyampaikan:

"Setelah saya membaca kembali, ternyata soal cerita yang saya buat tidak kontekstual."

Hal tersebut menunjukkan bahwa partisipan A menemukan positive understanding monitoring, yaitu penjelasan yang berakhir dengan memahami bagaimana membuat soal cerita yang kontekstual.

Sementara partisipan B menyampaikan:

"Saya merasa soal saya sudah bagus, tapi saya akui ada informasi yang hilang, yaitu 1/2 jam adalah waktu yang dibutuhkan untuk sampai di kampus dengan kondisi terjebak macet."

Hal tersebut menunjukkan bahwa partisipan $\mathrm{B}$ menemukan positive understanding monitoring, yaitu penjelasan yang berakhir dengan memahami bahwa ada informasi yang hilang pada soal. Pada konteks ini Selfexplanation mendorong peserta didik menjelaskan pengetahuan konseptual dan prosedural yang benar atau salah melalui tiga aktivitas, yaitu membandingkan, menjelaskan sendiri, dan mengeksplorasi (Rittle-Johnson, 2017; Rittle-Johnson et al., 2017), sehingga dari hasil eksplorasi lebih lanjut partisipan B menyadari bahwa ada ill-structured pada soal yang dibuat. Hal yang terjadi ketika penyusunan soal cerita pada soal kedua ini adalah partisipan A dan B mengalami perbedaan dalam kategori elaboration of problem.

Temuan dalam penelitian ini, yaitu jika partisipan melibatkan pemahaman maka keputusan yang diambil memunculkan positive understanding monitoring dan sebaliknya jika tidak melibatkan pemahaman maka keputusan yang diambil memunculkan negative understanding monitoring. Namun, terdapat partisipan yang hanya mengandalkan pengalaman dalam membuat soal dan berakhir dengan positive understanding monitoring.

\section{KESIMPULAN DAN SARAN}

Berdasarkan hasil dan pembahasan, diperoleh informasi terkait self-explanation dalam penyusunan soal cerita yang dilakukan yaitu: (1) pada soal pertama, partisipan memunculkan perbedaan pada kategori positive dan negative understanding monitoring. Positive understanding monitoring muncul ketika partisipan memiliki 
pemahaman terkait ide soal cerita yang disusun. Pemahaman tersebut dikaitkan dengan pengalaman dalam kehidupan sehari-hari. Sedangkan, negative understanding monitoring muncul ketika partisipan memiliki pemahaman, namun tidak dapat mengaitkan ide dan pemahamannya dengan pengalaman dalam kehidupan sehari-hari; (2) pada soal kedua, perbedaan muncul pada kategori elaboration of problem. Hal tersebut terjadi karena partisipan menggunakan informasi tidak langsung berdasarkan pengalaman dalam pembelajarannya.

Keterbatasan dalam penelitian ini adalah pengumpulan data yang hanya dilakukan melalui wawancara untuk menggali self-explanation. Jika pengumpulan data dilengkapi dengan proses think aloud maka diharapkan data yang diperoleh dapat memunculkan kategori self-explanation lainnya. Oleh karena itu, dapat dilakukan penelitian lebih lanjut terkait penyusunan soal cerita dengan self-explanation menggunakan think aloud.

\section{DAFTAR PUSTAKA}

Baars, M., Leopold, C., \& Paas, F. (2018). Self-explaining steps in problem-solving tasks to improve self-regulation in secondary education. Journal of Educational Psychology, 110(4), 578-595. https://doi.org/10.1037/edu000022 3

Bisra, K., Liu, Q., Nesbit, J. C., Salimi, F., \& Winne, P. H. (2018). Inducing Self-Explanation: a MetaAnalysis. Educational Psychology Review.

https://doi.org/10.1007/s10648018-9434-x

Chi, M. T. H. (2000). Self-explaining expository texts: The dual processes of generating inferences and repairing mental models. In Advances in instructional psychology.

DeCaro, M. S., \& Rittle-Johnson, B. (2012). Exploring mathematics problems prepares children to learn from instruction. Journal of Experimental Child Psychology, 113(4), 552-568. https://doi.org/10.1016/j.jecp.2012. 06.009

Dixon, J. K., Andreasen, J. B., Avila, C. L., Bawatneh, Z., Deichert, D. L., Howse, T. D., \& Turner, M. S. (2014). Redefining the Whole: Common Errors in Elementary Preservice Teachers' SelfAuthored Word Problems for Fraction Subtraction. Investigations in Mathematics Learning. https://doi.org/10.1080/24727466.2 014.11790336

Durkin, K. (2011). The self-explanation effect when learning mathematics: a meta-analysis. Conference on Building and Educatioan Science: Investigating Mechanisms.

Fuchs, L. S., Malone, A. S., Schumacher, R. F., Namkung, J., Hamlett, C. L., Jordan, N. C., Siegler, R. S., Gersten, R., \& Changas, P. (2016). Supported self-explaining during fraction intervention. Journal of Educational Psychology. https://doi.org/10.1037/edu000007 3

Fuchs, L. S., Malone, A. S., Schumacher, R. F., Namkung, J., \& Wang, A. (2015). Action, interaction, intervention. Action, Interaction, Intervention, 1-27. https://doi.org/10.3726/978-30352-0239-7 
Hadi, A. La, \& Kadir. (2017). Kemampuan Calon Guru dalam Mengajukan Masalah Contextual Word Problems Tentang Pengurangan Pecahan. April, 178-188.

Heitzmann, N., Fischer, F., \& Fischer, M. R. (2018). Worked examples with errors: when self-explanation prompts hinder learning of teachers diagnostic competences on problem-based learning. Instructional Science, 46(2), 245271.

https://doi.org/10.1007/s11251017-9432-2

Işik, C., \& Kar, T. (2012). An error analysis in division problems in fractions posed by pre-service elementary mathematics teachers. Educational Sciences: Theory and Practice.

Killingsworth, S. S., Clark, D. B., \& Adams, D. M. (2015). SelfExplanation and Explanatory Feedback in Games: Individual Differences, Gameplay, and Learning. International Journal of Education in Mathematics, Science and Technology, 3(3), 162. https://doi.org/10.18404/ijemst.156 00

Koedinger, K. R., Corbett, A. T., \& Perfetti, C. (2012). The Knowledge-Learning-Instruction Framework: Bridging the SciencePractice Chasm to Enhance Robust Student Learning. Cognitive Science. https://doi.org/10.1111/j.15516709.2012.01245.x

Mpofu, S., \& Pournara, C. (2018). Learner Participation in the Functions Discourse: A Focus on Asymptotes of the Hyperbola. African Journal of Research in
Mathematics, Science and Technology Education. https://doi.org/10.1080/18117295.2 017.1409170

Nanna, A. W. I., \& Pratiwi, E. (2020). Students ' Cognitive Barrier in Problem Solving: Picture -based Problem-solving. Al-Jabar: Jurnal Pendidikan Matematika.

Newton, K. J. (2008). An extensive analysis of preservice elementary teachers' knowledge of fractions. American Educational Research Journal, 45(4), 1080-1110. https://doi.org/10.3102/000283120 8320851

Nokes-Malach, T. J., VanLehn, K., Belenky, D. M., Lichtenstein, M., \& Cox, G. (2013). Coordinating principles and examples through analogy and self-explanation. European Journal of Psychology of Education, 28(4), 1237-1263. https://doi.org/10.1007/s10212012-0164-z

Pratiwi, E., Nusantara, T., Susiswo, S., Muksar, M., \& Subanji, S. (2019a). Characteristics of students' cognitive conflict in solving a problem based on information processing theory. International Journal of Learning, Teaching and Educational Research. https://doi.org/10.26803/ijlter.18.2. 6

Pratiwi, E., Nusantara, T., Susiswo, S., Muksar, M., \& Subanji, S. (2019b). Characteristics of students' cognitive conflict in solving a problem based on information processing theory. International Journal of Learning, Teaching and Educational Research, 18(2), 76-88. https://doi.org/10.26803/ijlter.18.2. 6 
Renkl, A. (1997). Learning from worked-out examples: A study on individual differences. Cognitive Science, 21(1), 1-29. https://doi.org/10.1207/s15516709 cog2101_1

Rittle-johnson, B. (2004). Proceedings of the Annual Meeting of the Cognitive Science Promoting Flexible Problem Solving: The Effects of Direct Instruction and Self-Explaining.

Rittle-Johnson, B. (2017). Developing Mathematics Knowledge. Child Development Perspectives, 11(3), 184-190.

https://doi.org/10.1111/cdep.12229

Rittle-Johnson, B., Loehr, A. M., \& Durkin, K. (2017). Promoting selfexplanation to improve mathematics learning: A metaanalysis and instructional design principles. ZDM - Mathematics Education, 49(4), 599-611. https://doi.org/10.1007/s11858017-0834-z

Safriani, W., Munzir, S., Duskri, M., \& Maulidi, I. (2019). Analysis of Students' Errors on the Fraction Calculation Operations Problem. Al-Jabar: Jurnal Pendidikan Matematika, 10(02), 307-318.

Shin, M., \& Bryant, D. P. (2017). Improving the Fraction Word Problem Solving of Students With Mathematics Learning Disabilities: Interactive Computer Application. Remedial and Special Education, $38(2)$, 76-86. https://doi.org/10.1177/074193251 6669052
Shulman, L. S. (2019). Those who understand: Knowledge growth in teaching. Profesorado. https://doi.org/10.30827/profesorad o.v23i3.11230

Tajika, H., Nakatsu, N., Nozaki, H., Neumann, E., \& Maruno, S. (2007). Effects of self-explanation as a metacognitive strategy for solving mathematical word problems $1 . \quad$ Japanese Psychological Research, 49(3), 222-233. https://doi.org/10.1111/j.14685884.2007.00349.x

Tichá, M., \& Hošpesová, A. (2013). Developing teachers' subject didactic competence through problem posing. Educational Studies in Mathematics, 83(1), 133-143.

https://doi.org/10.1007/s10649012-9455-1

Wang, Z., \& Adesope, O. (2017). Do focused self-explanation prompts overcome seductive details? A multimedia study. Educational Technology and Society, 20(4), 4757. 